\title{
Faktor Dominan dari Preferensi Konsumen dalam Pemilihan Jenis Mangga (Mangifera indica): Suatu Kasus di Supermarket di Kota Bandung
}

\author{
Didit Hadayanti ${ }^{1,2}$, Yosini Deliana ${ }^{3}$, dan Ronnie Susman Natawidjaja ${ }^{3}$ \\ ${ }^{1}$ Fakultas Teknologi Pertanian, Universitas Al-Ghifari Bandung \\ Jl. Cisaranten Kulon No. 140 Soekarno Hatta, Bandung 40293 \\ ${ }^{2}$ Alumni Program Studi Magister Ekonomi Pertanian, Fakultas Pertanian, \\ Universitas Padjadjaran \\ ${ }^{3}$ Departemen Sosial Ekonomi, Fakultas Pertanian, Universitas Padjadjaran \\ *Alamat korespondensi: didithadayanti@gmail.com
}

\begin{abstract}
Dominant Factors of Consumer Preferences in the Selection of Mango Fruit Types: A case in Supermarket in Bandung City
\end{abstract}

Mango is a fruit with high demand because of its good taste, its other benefits, and its important role as agricultural commodity in national economy. Along with the increase of people's income and health awareness, the demand for mango is growing. This study was aimed to analyze consumer preferences in selecting a mango type and to identify the dominant factors that distinguish consumers in preferring certain types of mangoes. The study used a quantitative method using survey techniques that was conducted in two different supermarkets located in Bandung City. The objects of the experiment were four mango types of Gedong gincu, Aromanis, Cengkir and Kaweni. The sampling method used was systematic random sampling with the respondents surveyed were the consumers who purchased mango in the research locations. The analytical method used was Discriminant Analysis to determine whether there was a clear distinction between the types of preferred mangoes in the characteristic variable of mango consumers and which dominant factors of the independent variable that makes the difference. The results showed that the preferences of consumers have a tendency to like Gedong gincu mango and the age and consumer consumption pattern were the dominant factors that influenced consumer preference in the mango choice.

Keywords: Consumer preference, Mango, Supermarket

\begin{abstract}
ABSTRAK
Buah mangga merupakan buah-buahan yang banyak diminati oleh masyarakat karena rasanya yang enak dan banyak manfaatnya. Seiring dengan pendapatan masyarakat dan kesadaran tentang kesehatan yang meningkat, permintaan akan buah mangga semakin besar. Penelitian ini bertujuan untuk menganalisis preferensi konsumen dalam memilih mangga dan mengidentifikasi faktor dominan yang membedakan konsumen menyukai jenis mangga tertentu. Penelitian ini menggunakan metode kuantitatif dengan menggunakan teknik survei yang dilakukan di dua supermarket di Kota Bandung. Objek yang diteliti adalah empat jenis buah mangga yaitu Gedong gincu, Aromanis, Cengkir dan Kaweni. Metode pengambilan sampel yang digunakan adalah systematic random sampling dengan responden yang disurvei adalah konsumen yang berbelanja buah mangga. Metode analisis yang digunakan adalah Analisis Diskriminan yang digunakan untuk mengetahui apakah ada perbedaan yang jelas antar jenis buah mangga yang disukai pada variabel karaktersitik konsumen mangga dan faktor-faktor dominan manakah dari variabel independen yang membuat perbedaan tersebut. Hasil penelitian menunjukkan bahwa preferensi konsumen mempunyai kecenderungan menyukai mangga Gedong gincu serta faktor umur dan pola konsumsi
\end{abstract}


konsumen adalah faktor dominan yang berpengaruh terhadap preferensi konsumen dalam pemilihan jenis mangga.

Kata Kunci: Preferensi konsumen, Mangga, Supermarket

\section{PENDAHULUAN}

Buah mangga (Mangifera indica) merupakan buah yang banyak diminati masyarakat karena rasanya yang enak dan banyak manfaatnya. Data BPS melalui sensus pertanian 2013 menunjukkan bahwa jumlah produksi buah mangga di Jawa Barat mencapai 434.939 ton, sedangkan produksi Jawa Timur mencapai 731.193 ton, dan produksi Jawa Tengah mencapai 403.939 ton. Produksi buah mangga di Jawa Barat dihasilkan dari daerah Cirebon, Indramayu, Majalengka dan Kuningan.

Provinsi Jawa Barat merupakan salah satu wilayah andalan pengembangan mangga di Indonesia yang memberikan kontribusi tertinggi kedua setelah Provinsi Jawa Timur. Luas panen mangga di Jawa Barat tahun 2003 mencapai 7.424 ha dengan total produksi 141.064 ton, atau setara dengan produktivitas 190 kwintal per ha. Lima jenis mangga utama yang dikembangkan di sentra mangga Jawa Barat yang meliputi kabupaten Majalengka, Cirebon dan Indramayu adalah mangga harumanis, gedong, Gedong gincu, dermayu dan golek. Pengembangan komoditas mangga di beberapa daerah di wilayah Kabupaten Majalengka, telah banyak dilakukan baik secara individu maupun dalam kaitan dengan program pengembangan komoditas unggulan daerah melalui suatu sistem agribisnis (Anugrah, 2009).

Penelitian ini dilakukan di kota Bandung, karena kota Bandung merupakan salah satu kota besar sebagai tempat penjualan buah mangga. Bandung merupakan kota nomor ke-3 di Indonesia dengan tingkat pendapatan yang cukup tinggi dan pola konsumsinya selalu dijadikan barometer oleh peretail, serta dijadikan tren permintaan konsumen. Selama beberapa dekade terakhir, kebiasaan konsumsi makanan memiliki perubahan sangat pesat. Peningkatan kehidupan manusia dan kesadaran tentang kebutuhan gizi dan kesehatan telah mendorong meningkatnya permintaan buah untuk konsumsi (Bonilla, 2010). Buah-buahan diakui memberi manfaat untuk hidup menuju sehat, buahbuahan memiliki penting vitamin, mineral, dan serat. Diet tinggi buah terkait dengan risiko yang lebih rendah untuk beberapa penyakit kronis denegeratif, termasuk kanker tertentu dan penyakit kardiovaskular (van Duyn \& Pivonka, 2000 dalam Bonilla, 2010).

Dengan adanya Masyarakat Ekonomi Asean (MEA), produk-produk buah impor akan semakin banyak masuk ke Indonesia. Namun demikian, buah-buahan lokal masih menjadi buah-buahan yang banyak dibeli konsumen. Menurut JeffersonMoore et al. (2014), faktor yang menyebabkan keputusan untuk membeli makanan lokal adalah atribut yang konsisten pada buah-buahan lokal seperti lebih sehat, terjangkau, dukungan masyarakat, kualitas, rasa, warna, gizi, harga, dan kesegaran. Produksi buah mangga berlimpah dan bermacam-macam jenisnya. Oleh karena itu, karakteristik konsumen berperan penting dalam memberikan informasi kepada petani dan para pelaku pasar buah mangga seperti contohnya jenis buah manga yang disukai oleh konsumen. Buah mangga yang dihasilkan petani apabila tidak disukai oleh konsumen, maka buah mangga tersebut tidak akan dibeli oleh konsumen dan konsumen akan beralih membeli produk alternatif lainnya. Selain itu, buah-buahan bisa saling menggantikan satu dengan yang lainnya tanpa ada masalah sehingga dalam hal ini karakteristik konsumen menjadi hal yang penting. Tidak terpenuhinya karakteristik konsumen untuk kualitas tertentu, bisa membuat konsumen meninggalkan buah-buahan local, dalam hal ini buah mangga lokal. Penelitian ini bertujuan untuk mengetahui faktor dominan dari preferensi konsumen dalam pemilihan jenis buah manga.

\section{BAHAN DAN METODE}

Penelitian ini dilaksanakan pada bulan September hingga Oktober 2015. Objek penelitian yang diteliti adalah empat jenis buah mangga yaitu Gedong gincu, Aromanis, Cengkir dan Kaweni. Lokasi penelitian diambil secara sengaja (purposive) di dua supermarket di Kota Bandung. Penelitian ini dilakukan dengan menggunakan metode kuantitatif dengan menggunakan teknik survei. Metode pengambilan sampel yang digunakan adalah Sytematic Random Sampling yaitu pengambilan sampel berdasarkan waktu. Responden yang disurvei 
adalah responden yang membeli buah mangga. Dari satu responden ke responden lainnya berjarak 15 menit. Di dalam penelitian ini diambil 120 sampel dari dua supermarket, masing-masing supermarket jumlahnya 60 orang.

Dalam penelitian digunakan analisis diskriminan untuk mengetahui apakah ada perbedaan yang jelas antar jenis buah mangga yang disukai pada variabel karakteristik konsumen mangga (Gedong gincu, Aromanis, Cengkir dan Kaweni). Selanjutnya, bila ada perbedaan, maka faktor-faktor dominan manakah dari variabel independen yang membuat perbedaan tersebut. Model analisis diskriminan dalam penelitian ini adalah teknik multivariat yang termasuk metode dependen yaitu adanya variabel dependen dan independen. Dengan demikian ada variabel yang hasilnya tergantung dari data variabel independen. Ciri khusus adalah data variabel dependen yang harus berupa data kategori sedangkan data independen berupa non kategori. Bentuk multivariat dari analisis diskriminan adalah dependen, maka variabel dependen menjadi dasar analisis diskriminan (Santoso, 2004). Model Analisis Diskriminan adalah sebagai berikut:

$\mathrm{Y}_{1}=\mathrm{X}_{1}+\mathrm{X}_{2}+\ldots+\mathrm{X}_{\mathrm{n}}$

Keterangan:

$\mathrm{Y}_{1}=$ Jenis Mangga yang disukai

$\mathrm{X}_{1}=$ Usia

$\mathrm{X}_{2}=$ Tingkat Pendapatan

$\mathrm{X}_{3}=$ Tingkat Pendidikan

$\mathrm{X}_{4}=$ Jumlah keluarga

$\mathrm{X}_{5}=$ Pola Konsumsi Buah-buahan

Prinsip Diskriminan adalah ingin membuat

model yang dapat secara jelas menunjukkan perbedaan (diskriminasi) antar isi variabel dependen. Dalam melakukan proses analisis diskriminan ini digunakan alat bantu perangkat lunak (software) SPSS 17 for Windows.

\section{HASIL DAN PEMBAHASAN}

\section{Karakteristik Konsumen}

Berdasarkan Tabel 1 dapat dilihat bahwa usia responden paling terbanyak pada usia $31-40$ tahun $(35,8 \%)$, usia ini merupakan usia produktif. Rentang usia akhir 20an tahun dan usia antara 30-40 tahun adalah awal matangnya keuangan dan karir sehingga akan ada kecenderungan membeli barang yang sudah tergolong untuk memenuhi kebutuhan aktualisasi diri seperti membeli makanan yang sehat. Hal ini berbanding lurus dengan semakin tinggi selera yang diinginkan, seiring meningkatnya penghasilan konsumen. Pada konsumen yang berumur lebih dari 40 tahun, mempunyai kecenderungan lebih menyukai mangga yang rasanya manis, dibandingkan umur di bawah 40 tahun lebih bervariasi seperti rasa mangga yang manis asam, manis ataupun yang rasa asam.

Tabel 1. Karakteristik konsumen buah mangga.

\begin{tabular}{|c|c|c|}
\hline Karakteristik konsumen & Frekuensi & Persentase \\
\hline \multicolumn{3}{|l|}{ Usia } \\
\hline $20-30$ & 18 & 18,3 \\
\hline $31-40$ & 36 & 35,8 \\
\hline $41-50$ & 32 & 32,5 \\
\hline $51-60$ & 11 & 10,8 \\
\hline$>60$ & 3 & 2,5 \\
\hline \multicolumn{3}{|l|}{ Jenis kelamin } \\
\hline Perempuan & 102 & 85 \\
\hline Laki-laki & 18 & 15 \\
\hline \multicolumn{3}{|l|}{ Tingkat kendidikan } \\
\hline SMA & 22 & 21,7 \\
\hline D3 & 11 & 10,8 \\
\hline S1 & 59 & 59,2 \\
\hline S2 & 8 & 8,3 \\
\hline \multicolumn{3}{|l|}{ Tingkat kendapatan } \\
\hline $2-3$ juta & 33 & 27,5 \\
\hline 4-5 juta & 43 & 35,8 \\
\hline 6-7 juta & 10 & 8,3 \\
\hline 8-9 juta & 9 & 7,5 \\
\hline$>9$ juta & 25 & 20,8 \\
\hline \multicolumn{3}{|l|}{ Jumlah anggota keluarga } \\
\hline 1 orang & 11 & 10,8 \\
\hline 2 orang & 21 & 16,7 \\
\hline 3 orang & 34 & 28,3 \\
\hline 4 orang & 38 & 30,8 \\
\hline$>4$ orang & 16 & 13,3 \\
\hline \multicolumn{3}{|l|}{ Pekerjaan } \\
\hline PNS & 12 & 10,0 \\
\hline Karyawan Swasta & 67 & 55,8 \\
\hline Ibu rumah tangga & 26 & 21,7 \\
\hline Pengusaha & 8 & 6,7 \\
\hline Lainnya & 7 & 5,8 \\
\hline
\end{tabular}

Konsumen mangga yang berjenis kelamin perempuan (85\%) lebih banyak dari pada laki-laki (15\%). Hasil menunjukkan bahwa preferensi konsumen dipengaruhi oleh jenis kelamin. Shaharuddin et al. (2015) menyebutkan bahwa jenis 
kelamin berpengaruh terhadap preferensi konsumen. Berdasarkan jenis kelamin kesukaan konsumen atas buah mangga ada sedikit perbedaan, untuk laki-laki kecenderungan penilaian lebih terhadap rasa, menyukai rasa mangga yang manis, dan tidak terlalu memperdulikan terhadap atribut mangga lainnya, sedangkan kesukaan untuk perempuan lebih menyeluruh penilaian terhadap rasa, warna, aroma, ukuran, tekstur, dan derajat kematangan mangga sangat diperhatikan. Untuk rasa ada yang menyukai rasa manis dan rasa manis asam, untuk warna rata-rata perempuan menyukai warna mangga yang kuning kemerahan yang mengindikasikan bahwa mangga tersebut sudah matang dan rasanya manis, untuk aroma rata-rata perempuan menyukai aroma mangga yang wangi dan sebagian perempuan menyukai aroma sangat wangi. Untuk tekstur rata-rata perempuan menyukai tekstur mangga yang cukup dan agak lunak untuk mangga Gedong gincu, mangga Aromanis dan Kaweni, sedangkan untuk mangga Cengkir rata-rata perempuan menyukai tekstur keras dan agak keras. Untuk ukuran mangga, ratarata perempuan menyukai ukuran sedang utuk mangga Gedong gincu, Aromanis, dan Kaweni, sedangkan untuk mangga Cengkir rata-rata perempuan menyukai ukuran besar. Untuk derajat kematangan perempuan menyukai derajat kematangan buah yang matang artinya sudah siap konsumsi dan mempunyai rasa mangga yang manis.

Berdasakan Tabel 1 dapat diketahui bahwa pendapatan konsumen mangga paling banyak pada 4-5 juta rupiah/bulan. Pendapatan 4-5 juta/bulan merupakan pendapatan di atas UMR Bandung sebesar 2,3 juta. Dengan demikian, rata-rata konsumen mangga adalah kelas menengah. Pilihan produk sangat dipengaruhi oleh keadaan ekonomi. Dalam hal ini tingkat pendapatan pada jenis pendapatan yang dapat dibelanjakan (tingkat, stabilitas, dan pola waktu), tabungan dan asset (termasuk persentase asset likuid, utang, kekutan pinjaman, dan sikap terhadap pengeluaran dan tabungan) (Kotler, 2009). Dengan demikian, seperti disebutkan Kotler (2009) bahwa selera konsumen dalam makanan, pakaian, perabot dan rekreasi sering berhubungan dengan tingkat pendapatan konsumen. Semakin tinggi tingkat pendapatan konsumen akan cenderung mengarahkan pada pemilihan dan pemenuhan kebutuhan sesuai yang diinginkan konsumen. Konsumen yang mempunyai tingkat pendapatan yang tinggi cenderung menyukai mangga Gedong gincu, tetapi ada juga yang menyukai mangga Aromanis, Cengkir dan Kaweni walaupun tingkat pendapatannya tinggi, sehingga tidak bisa disamaratakan kesukaan konsumen yang mempunyai tingkat pendapatan tinggi pasti menyukai mangga Gedong gincu. Konsumen yang tingkat pendapatannnya menengah ada kecenderungan menyukai mangga Gedong gincu dan Aromanis, sedangkan untuk tingkat pendapatan yang rendah, konsumen cenderung menyukai mangga Aromanis dikarenakan harganya lebih murah dari Gedong gincu tetapi mangga Aromanis kualitasnya sudah baik dari segi rasa yang manis.

Berdasakan Tabel 1 dapat diketahui bahwa konsumen yang tingkat pendidikannya S1 mempunyai jumlah tertinggi sebanyak 59 responden $(59,2 \%)$. Semakin tinggi tingkat pendidikan maka akan semakin luas wawasan dan pengetahuannya. Seseorang yang mempunyai tingkat pendidikan yang lebih tinggi akan cenderung kritis dalam segala rasional dalam mempertimbangkan suatu keputusan, termasuk dalam memilih makanan yang sehat yang akan dikonsumsi. Buah mangga merupakan salah satu pilihan buah-buahan untuk memenuhi kebutuhan konsumen sebagai sumber vitamin dan mineral serta sebagai antioksidan. Supermarket 1 dan 2 termasuk Toko kelas menengah, sehingga ratarata konsumen yang datang berbelanja mempunyai tingkat pendidikan yang cukup tinggi yaitu S1. Konsumen dengan tingkat pendidikan yang tinggi akan lebih kritis dalam memilih suatu produk. Namun demikian, di dalam peneitian ini konsumen dengan tingkat pendidikan yang tinggi tidak berbanding lurus dengan tingkat kesukaannya, tidak semua konsumen yang berpendidikan tinggi semuanya menyukai mangga Gedong gincu yang merupakan ratu dari semua mangga. Konsumen yang mempunyai tingkat pendidikan yang tinggi ada pula yang menyukai mangga Aromanis ataupun mangga Cengkir. Tetapi dari hasil penelitian, konsumen paling banyak menyukai mangga Gedong gincu dan Aromanis karena kedua mangga ini memiliki kualitas yang baik dari segi rasa, warna, aroma, tekstur, ukuran dan derajat kematangan.

Jumlah responden terbanyak memiliki jumlah keluarga sebanyak 4 orang (Tabel 1). Jumlah tanggungan keluarga adalah jumlah orang yang dibiayai oleh responden. Jumlah tanggungan keluarga berbanding lurus dengan biaya kebutuhan. Keluarga yang berukuran besar total pengeluaran untuk bahan makanan akan lebih tinggi. Apabila pendapatan keluarga sama, maka keluarga dengan jumlah anggotanya yang lebih sedikit mempunyai 
susunan makanan sehari-hari dalam keadaan yang cukup memenuhi dibandingan dengan jumlah anggota keluarganya yang banyak bisa kekurangan. Besar kecilnya jumlah anggota keluarga diduga ikut berperan terhadap pembuat keputusan dalam mengkonsumsi suatu produk dan menyesuaikannya dengan sumberdaya ekonominya. Dari hasil penelitian terlihat bahwa jumlah anggota keluarga dalam penelitian ini tidak terlalu berpengaruh dalam preferensi konsumen, karena tidak menunjukkan bahwa jumlah anggota keluarga yang lebih banyak maka konsumen memilih mangga Kaweni yang dilihat dari segi harga paling murah dari keempat mangga yang diteliti. Demikian juga sebaliknya, konsumen yang memiliki jumlah anggota keluarga sedikit tidak memilih mangga Gedong Gicu yang memiliki harga yang paling tinggi.

Pekerjaan konsumen mangga paling terbanyak adalah karyawan swasta sebesar 55,8\%. Semakin banyaknya perusahaan-perusahaan yang melakukan investasi di Kota Bandung memperluas jumlah tenaga kerja yang bekerja di sektor swasta. Hal ini dikarenakan banyak perusahaan swasta yang tersebar di kota Bandung, sehingga banyak konsumen yang memiliki pekerjaan sebagai karyawan swasta serta letak dua supermarket ini berada di tengah kota, dekat dengan perkantoran perusahaan swasta. Kesukaan konsumen tertinggi dari segi pekerjaan adalah konsumen yang menyukai mangga Gedong gincu, kemudian mangga Aromanis. Konsumen dengan pekerjaan karyawan swasta cenderung menyukai Gedong gincu karena karakteristik yang dimiliki oleh mangga Gedong gincu dengan rasa manis asam yang khas yang tidak dimiliki oleh mangga yang lain.

\section{Jenis Mangga yang Disukai}

Berdasarkan Tabel 2 dapat dilihat bahwa konsumen terbanyak adalah konsumen yang mempunyai preferensi terhadap mangga Gedong gincu dengan jumlah 66 orang (55\%). Banyaknya konsumen yang lebih menyukai mangga Gedong gincu pernah dilaporkan sebelumnya dimana disebutkan bahwa mangga Gedong gincu merupakan jenis manga yang meskipun memiliki harga yang paling tinggi tetapi permintaan pasar pada jenis mangga ini sangat tinggi baik untuk pasar dalam negeri maupun ekspor (Sulistyowati, 2014).

\section{Uji Kelayakan Variabel Dependen untuk Dianalisis}

Pada awal proses pengujian menunjukkan bahwa grup dalam variabel dependen yaitu grup
'Kaweni' mempunyai jumlah data yang terlalu sedikit (4 responden) sehingga nilai Log Determinant untuk grup ini tidak bisa ditentukan dan tidak bisa diikutkan dalam analisis. Oleh karena itu, analisis determinan hanya dilakukan dengan 3 grup saja. Hasil Box's M Test menunjukkan bahwa angka Sig. adalah sebesar 0,055 yang lebih besar dari 0,05 . Hal ini menunjukkan bahwa matriks kovarians grup adalah sama (equal). Hal ini berarti bahwa data sudah memenuhi asumsi diskriminan yaitu bahwa variabel independen berbeda secara nyata berdasar pada variabel dependen sehingga proses bisa dilanjutkan.

Tabel 2. Jenis mangga yang paling disukai konsumen.

\begin{tabular}{|c|c|c|c|}
\hline \multirow{2}{*}{ Jenis mangga } & & \multicolumn{2}{|c|}{ Frekuensi } \\
\hline & & $\mathrm{N}$ & $\%$ \\
\hline Gedong gincu & & 66 & 55 \\
\hline Aromanis & & 30 & 25 \\
\hline Cengkir & & 20 & 17 \\
\hline Kaweni & & 4 & 3 \\
\hline Total & & 120 & 100 \\
\hline \multicolumn{4}{|c|}{ Tabel 3. Log determian grup variabel dependen. } \\
\hline $\begin{array}{c}\text { Grup variabel } \\
\text { dependen }\end{array}$ & Frekuensi & $\log$ & ninan \\
\hline Gedong gincu & 66 & \multicolumn{2}{|c|}{ ada } \\
\hline Aromanis & 30 & \multicolumn{2}{|c|}{ ada } \\
\hline Cengkir & 20 & \multicolumn{2}{|c|}{ ada } \\
\hline Kaweni & 4 & \multicolumn{2}{|c|}{ tidak bisa ditentukar } \\
\hline
\end{tabular}

\section{Hasil Analisis}

Berdasarkan Tabel 4 terlihat bahwa terdapat dua variabel bebas yaitu variabel usia dan pola konsumsi buah-buahan. Kedua variabel tersebut mempunyai nilai Sig. yang lebih kecil dari 0,05, sedangkan variabel tingkat pendapatan, tingkat pendidikan dan jumlah anggota keluarga mempunyai nilai Sig. yang lebih besar dari 0,05 sehingga tidak signifikan. Berdasarkan hal tersebut maka dapat disimpulkan bahwa terdapat perbedaan yang signifikan antara preferensi konsumen terhadap ketiga jenis mangga (Gedong gincu, Aromanis dan Cengkir) karena terdapat minimal 1 variabel bebas yang menjadi pembedanya. Dalam hal ini, terdapat dua variabel bebas yang menjadi pembeda yaitu variabel Usia dan Pola konsumsi mangga. 
Tabel 4. Uji kesamaan nilai rata-rata grup.

\begin{tabular}{lcccccl}
\hline \multicolumn{1}{c}{ Variabel bebas } & Wilks' Lambda & F & df1 & df2 & Sig. & Ket \\
\hline Usia (tahun) & 0,871 & 8,339 & 2 & 113 & 0,000 & Signifikan $^{* * *}$ \\
Tingkat pendapatan (Juta/Bulan) & 0,961 & 2,281 & 2 & 113 & 0,107 & Tidak signifikan \\
Tingkat pendidikan & 0,994 & 0,369 & 2 & 113 & 0,692 & Tidak signifikan \\
Jumlah anggota keluarga (orang) & 0,950 & 2,971 & 2 & 113 & 0,055 & Tidak signifikan \\
Pola konsumsi mangga & 0,924 & 4,662 & 2 & 113 & 0,011 & Signifikan $^{* *}$ \\
\hline
\end{tabular}

Keterangan: ${ }^{* * *}$ (Signifikan dengan tingkat kepercayaan 99\%); ${ }^{* *}$ (Signifikan dengan tingkat kepercayaan 95\%).

Berdasarkan Tabel 5 terlihat jarak antara grup mangga Cengkir dengan Aromanis adalah yang terbesar yaitu 10,814 diikuti oleh mangga Aromanis dan Gedong gincu dengan 6,489. Sedangkan jarak terkecil adalah antara Gedong gincu dan Cengkir yaitu 2,555. Angka-angka tersebut mengindikasikan bahwa konsumen yang menyukai mangga Cengkir paling berbeda profilnya (usia dan pola konsumsi mangganya) dibandingkan dengan konsumen yang menyukai mangga Aromanis. Sebaliknya umur dan pola konsumsi mangga pada konsumen yang menyukai mangga Cengkir mempunyai perbedaan yang kecil dengan konsumen yang menyukai mangga Gedong gincu.

Tabel 5. Pairwise Group Comparisons.

\begin{tabular}{llccc}
\hline \multicolumn{2}{c}{$\begin{array}{c}\text { Preferensi } \\
\text { konsumen }\end{array}$} & $\begin{array}{c}\text { Gedong } \\
\text { gincu }\end{array}$ & Aromanis & Cengkir \\
\hline Gedong & F & & 6,489 & 2,555 \\
gincu & Sig. & & 0,002 & 0,082 \\
Aromanis & F & 6,489 & & 10,814 \\
& Sig. & 0,002 & & 0,000 \\
Cengkir & F & 2,555 & 10,814 & \\
& Sig. & 0,082 & 0,000 & \\
\hline
\end{tabular}

Untuk lebih mendalami peran dari kedua variabel yang signifikan ini yaitu usia dan pola konsumsi mangga dalam menjadi diskriminan terhadap preferensi konsumen dilakukan analisis tabulasi silang. Analisis tabulasi silang dilakukan terhadap seluruh data (120 sampel responden) agar dapat memperlihatkan semua gejala yang terjadi pada seluruh data penelitian. Hasil analisis tabulasi silang antara preferensi konsumen mangga dengan variabel usia disajikan pada Tabel 6. Hasil menunjukkan bahwa sebaran preferensi konsumen mangga sangat berbeda pada semua tingkatan usianya. Hal yang terlihat sangat mencolok adalah bahwa konsumen yang menyukai mangga Gedong gincu berjumlah lebih dari 50\% untuk setiap tingkatan usia. Pada tingkatan usia 20-30 tahun dan 31-40 tahun, konsumen yang menyukai mangga aromanis merupakan yang terbanyak kedua setelah Gedong gincu dengan persentase lebih dari 34\% pada tiap tingkatan usia tersebut. Sedangkan pada tingkatan usia 41-50 tahun dan >50 tahun, yang mempunyai konsumen terbanyak kedua setelah mangga Gedong gincu adalah konsumen yang menyukai mangga Cengkir dengan 20,5\% dan $37,5 \%$. Sementara itu, konsumen yang menyukai mangga Kaweni selalu menjadi yang paling sedikit dengan persentase di bawah $10 \%$ pada semua tingkatan usia. Secara keseluruhan dapat disimpulkan bahwa konsumen yang paling menyukai buah mangga (semua jenis) adalah konsumen yang berusia 31-50 tahun dengan 82 orang atau $68,3 \%$ dari total responden, diikuti oleh konsumen berusia muda (20-30 tahun) sebanyak 22 orang $(18,3 \%)$ dan konsumen berusia $>50$ tahun sebanyak 16 orang (13,3\%). Selain itu, jika dikaitkan dengan hasil analisis diskriminan yang menyimpulkan bahwa konsumen yang menyukai mangga Cengkir paling berbeda profilnya dengan konsumen yang menyukai mangga Aromanis sedangkan antara mangga cengkir dan Gedong gincu profilnya cenderung mirip. Dapat dilihat dengan jelas pada Tabel 6 bahwa bahwa jika persentase jumlah konsumen yang menyukai mangga Cengkir naik dari satu tingkatan usia ke tingkatan usia yang lainnya maka pada konsumen yang menyukai mangga Aromanis terjadi penurunan persentase (kebalikannya) sedangkan pada konsumen yang menyukai mangga Gedong gincu sama-sama meningkat.

Dengan demikian pengaruh signifikan dari variabel usia dalam membedakan preferensi konsumen mangga telah terjelaskan. Berpengaruhnya faktor usia terhadap preferensi konsumen juga pernah disebutkan di dalam penelitian Shaharuddin et al. (2015) bahwa faktor usia berpengaruh terhadap preferensi konsumen. 
Disebutkan bahwa semakin dewasa usia konsumen baik dari segi kematangan berfikir/faktor edukatif yang diperoleh dari pendidikan dan kematangan dalam pengalamannya dengan bertambahnya usia maka akan semakin berkembang pula preferensinya terhadap suatu produk dan selanjutnya akan berpengaruh terhadap sikap maupun perilaku pembeliannya.

Tabel 6. Sebaran preferensi konsumen mangga berdasarkan usia.

\begin{tabular}{|c|c|c|c|c|c|c|}
\hline \multirow{2}{*}{ Usia } & & \multicolumn{4}{|c|}{ Jenis mangga yang disukai } & \multirow{2}{*}{ Total } \\
\hline & & Gedong gincu & Aromanis & Cengkir & Kaweni & \\
\hline \multirow[t]{2}{*}{ 20-30 tahun } & $\mathrm{N}$ & 11 & 8 & 1 & 2 & 22 \\
\hline & $\%$ & $50,0 \%$ & $36,4 \%$ & $4,5 \%$ & $9,1 \%$ & $100,0 \%$ \\
\hline \multirow[t]{2}{*}{ 31-40 tahun } & $\mathrm{N}$ & 22 & 15 & 5 & 1 & 43 \\
\hline & $\%$ & $51,2 \%$ & $34,9 \%$ & $11,6 \%$ & $2,3 \%$ & $100,0 \%$ \\
\hline \multirow[t]{2}{*}{$41-50$ tahun } & $\mathrm{N}$ & 23 & 7 & 8 & 1 & 39 \\
\hline & $\%$ & $59,0 \%$ & $17,9 \%$ & $20,5 \%$ & $2,6 \%$ & $100,0 \%$ \\
\hline \multirow[t]{2}{*}{$>50$ tahun } & $\mathrm{N}$ & 10 & 0 & 6 & 0 & 16 \\
\hline & $\%$ & $62,5 \%$ & $0,0 \%$ & $37,5 \%$ & $0,0 \%$ & $100,0 \%$ \\
\hline \multirow[t]{2}{*}{ Total } & $\mathrm{N}$ & 66 & 30 & 20 & 4 & 120 \\
\hline & $\%$ & $55,0 \%$ & $25,0 \%$ & $16,7 \%$ & $3,3 \%$ & $100,0 \%$ \\
\hline
\end{tabular}

Sebaran preferensi konsumen mangga dilihat dari pola konsumsi mangganya disajikan dalam Tabel 7. Pola konsumsi adalah susunan atau pola terhadap kebutuhan individu atau seseorang untuk memenuhi kebutuhan sehari-harinya. Pola konsumsi tiap-tiap orang pasti berbeda-beda karena beberapa faktor yang menyebabkannya. Dalam menyusun pola konsumsi, pada umumnya orang akan mendahulukan kebutuhan pokok. Tabel 7 menunjukkan bahwa secara keseluruhan seiring dengan meningkatnya pola konsumsi mangga maka jumlah respondennya juga menjadi meningkat. Banyaknya konsumen yang mengkonsumsi buah mangga setiap hari megindikasikan bahwa konsumen saat ini sudah menyadari akan pentingnya kesehatan tubuh yang memerlukan kecukupan gizi dari makanan setiap harinya.

Tabel 7. Sebaran preferensi konsumen mangga berdasarkan pola konsumsi mangga.

\begin{tabular}{|c|c|c|c|c|c|c|}
\hline \multirow{2}{*}{ Pola konsumsi mangga } & & \multicolumn{4}{|c|}{ Jenis mangga yang disukai } & \multirow{2}{*}{ Total } \\
\hline & & Gedong gincu & Aromanis & Cengkir & Kaweni & \\
\hline \multirow[t]{2}{*}{ Jarang mengkonsumsi } & $\mathrm{N}$ & 1 & 0 & 0 & 0 & 1 \\
\hline & $\%$ & $100,0 \%$ & $0,0 \%$ & $0,0 \%$ & $0,0 \%$ & $100,0 \%$ \\
\hline \multirow[t]{2}{*}{ Kadang-kadang mengkonsumsi } & $\mathrm{N}$ & 3 & 10 & 0 & 1 & 14 \\
\hline & $\%$ & $21,4 \%$ & $71,4 \%$ & $0,0 \%$ & $7,1 \%$ & $100,0 \%$ \\
\hline \multirow[t]{2}{*}{ Sering mengkonsumsi } & $\mathrm{N}$ & 11 & 1 & 3 & 2 & 17 \\
\hline & $\%$ & $64,7 \%$ & $5,9 \%$ & $17,6 \%$ & $11,8 \%$ & $100,0 \%$ \\
\hline \multirow[t]{2}{*}{ Setiap hari Mengkonsumsi } & $\mathrm{N}$ & 51 & 19 & 17 & 1 & 88 \\
\hline & $\%$ & $58,0 \%$ & $21,6 \%$ & $19,3 \%$ & $1,1 \%$ & $100,0 \%$ \\
\hline \multirow[t]{2}{*}{ Total } & $\mathrm{N}$ & 66 & 30 & 20 & 4 & 120 \\
\hline & $\%$ & $55,0 \%$ & $25,0 \%$ & $16,7 \%$ & $3,3 \%$ & $100,0 \%$ \\
\hline
\end{tabular}

Berdasarkan sebaran preferensi mangganya (Tabel 1), terlihat bahwa konsumen yang menyukai mangga Gedong gincu merupakan yang terbanyak dibandingkan mangga jenis lainnya pada 3 tingkatan pola konsumsi yaitu pada konsumen yang jarang menkonsumsi mangga, sering mengkonsumsi mangga dan yang setiap hari mengkonsumsi mangga dengan persentase yang cukup besar yaitu diatas $50 \%$ untuk setiap tingkatan pola konsumsi tersebut. Sementara itu, tingkatan konsumen yang kadangkadang mengkonsumsi mangga sebagian besar lebih menyukai mangga Aromanis dari pada mangga jenis 
lainnya dengan persentase $73 \%$. Hal yang menarik lainnya adalah tingkatan konsumen yang sering mengkonsumsi mangga lebih banyak menyukai mangga Cengkir dan Kaweni daripada Aromanis, pada tingkatan ini konsumen yang menyukai mangga Aromanis jumlahnya paling sedikit.

Selain itu, jika dikaitkan dengan hasil analisis diskriminan yang menyimpulkan bahwa konsumen yang menyukai mangga Cengkir paling berbeda profilnya dengan konsumen yang menyukai mangga Aromanis, sedangkan antara mangga Cengkir dan Gedong gincu profilnya cenderung mirip. Pada Tabel 7 dapat dilihat bahwa jika persentase jumlah konsumen yang menyukai mangga cengkir naik dari satu tingkatan pola konsumsi ke tingkatan pola konsumsi mangga yang lainnya maka pada konsumen yang menyukai mangga aromanis terjadi penurunan persentase (kebalikannya) sedangkan pada konsumen yang menyukai mangga Gedong gincu sama-sama meningkat. Dengan demikian pengaruh signifikan dari variabel pola konsumsi mangga dalam membedakan preferensi konsumen mangga telah terjelaskan.

\section{SIMPULAN DAN SARAN}

\section{Simpulan}

1. Preferensi

konsumen

mempunyai

kecenderungan menyukai mangga Gedong gincu karena rasa mangga Gedong gincu yang khas dengan rasa asam manis dibandingkan dengan mangga Aromanis, Cengkir dan Kaweni.

2. Faktor dominan yang berpengaruh terhadap preferensi konsumen dalam pemilihan jenis mangga adalah faktor usia dan pola konsumsi konsumen. Semakin tinggi tingkat usia maka semakin kritis konsumen dalam pemilihan suatu produk mangga yang berkualitas. Semakin tinggi pola konsumsi konsumen mangga maka semakin tinggi tingkat konsumsi konsumen terhadap buah mangga.

\section{Saran}

Untuk meningkatkan target pasarnya ke semua kalangan konsumen, petani mangga terutama petani mangga Aaromanis, Cengkir dan Kaweni harus memperbaiki kualitas produksinya menjadi lebih berorientasi (pasar modern) sehingga lebih komersial. Dalam hal ini pemerintah juga dapat berperan dalam upaya peningkatan kualitas produksi mangga dengan mendampingi petani dalam teknologi produksi yang sesuai standar serta memberikan teknologi kepada petani mangga Aromanis, Cengkir dan Kaweni untuk memenuhi supply mangga di luar musim sehingga harga ditingkat petani menjadi lebih tinggi.

\section{DAFTAR PUSTAKA}

Anugrah, IS. 2009. Mendudukan Komoditas Mangga Sebagai Unggulan Daerah dalam Suatu Kebijakan Sistem Agribisnis. Upaya Menyatukan Dukungan Kelembagaan bagi Eksistensi Petani. Analisis Kebijakan Pertanian Vol. 07 No. 02. Pusat Sosial Ekonomi dan Kebijakan Pertanian, Badan Penelitian dan Pengembangan Pertanian Kementrian Pertanian.

Badan Pusat Statistik. 2013. Produksi Buah-buahan. Tersedia online pada http://www.bps.go.id. Diakses pada tanggal 25 Desember 2014.

Bonilla, T. 2010. Analysis of Consumer Preferences Toward 100\% Fruit Juice Packages and Labels. Thesis. The Departement of agricultural Economios and Agribusiness. Universidad de Costa Rica, Costa Rica.

Jefferson-Moore, KY, RD Robbins, D Johnson, and J Bradford. 2014. Consumer Preferences for local food products in North Carolina. Journal of Food Distribution Research. 45 (1): 41-46.

Kotler, P. 2009. Manajemen Pemasaran. Edisi 13 Jilid 1. Erlangga, Jakarta.

Santoso, S. 2004. Latihan SPSS Statistik Multivariat. Elex Media Komputindo-Kelompok Gramedia, Jakarta.

Shaharuddin, S, A Zamaludin, R Hashim, MA Hadi, and LC Ming. 2015. Assessing consumer preference using community pharmacy preference evaluation questionnare (ComPeTe). A pilot survey in Malaysia City. Tropical Journal of Pharmaceutical Research. 14 (7): 1299-1303.

Sulistyowati, L, E Rasmikayati, dan N Syamsiah. 2014. Pengembangan Kemitraan Usaha dalam Upaya Meningkatkan Komersialisasi dan Pendapatan Petani Mangga. Universitas Padjadjaran. 